\title{
PEMANFAATAN MANURE HASIL DEGRADASI LARVA LALAT HITAM (Hermetia illucens L) SEBAGAI PENGGANTI TEPUNG IKAN TERHADAP PENAMPILAN AYAM BURAS FASE GROWER
}

\author{
Elvis N Simboh, H. J. Manangkot*, L. J. Lambey,L. M. S. Tangkau
}

\author{
Fakultas Peternakan Universitas Sam Ratulangi Manado, 95115
}

\begin{abstract}
ABSTRAK
Tujuan untuk mengetahui penampilan ayam buras betina fase grower yang diberikan tepung manure hasil degradasi larva $H$. illucens $L$. dengan menggantikan tepung ikan dalam ransum. Percobaan ini dilakukan dengan menggunakan rancangan acak lengkap (RAL) yang terdiri dari 4 perlakuan dan 5 ulangan. Perlakuan penelitian ini adalah $\mathrm{R} 0=$ Ransum dengan $15 \%$ tepung ikan +0 $\%$ tepung MHD R1= Ransum dengan $10 \%$ tepung ikan $+5 \%$ tepung MHD R2 = Ransum dengan $5 \%$ tepung ikan $+10 \%$ tepung MHD R3= Ransum dengan $0 \%$ tepung ikan $+15 \%$ tepung MHD. Variabel yang di ukur adalah jumlah kosumsi, pertambahan berat badan dan efisiensi penggunaan Ransum. Hasil penelitian yang di peroleh menunjukan perlakuan memberikan pengaruh yang tidak nyata $(\mathrm{P}>0,05)$ terhadap konsumsi, Pertambahan Berat badan dan efisiensi penggunaan Makanan.
\end{abstract}

Kata kunci: MHD, tepung ikan, lalat hitam ayam buras fase grower

\section{ABSTRACT}

\section{UTILIZATION MANURE DEGRADED USING BLACK FLY LARVAE (Hermetia illucens L) SUBSTITUTING FISH MEAL IN}

*Korespondensi (corresponding Author) Email : hmanangkot@yahoo.com
RATION ON LOCAL GROWING CHICKEN. The objective of this study was to evaluate the performance of local growing chicken fed ration containing manure flour degraded (MFD) by Larva of black fly (Hermetia illucens L). This experiment was carried out using a complete Randomized Design (RAL), consisted of 4 treatments and five replications in each treatment as follows: $\mathrm{R} 0=$ Rations with $15 \%$ fish meal $+0 \%$ MFD, R1 $=10 \%$ fish meal $+5 \%$ MFD, R2 $=5 \%$ fish meal $+10 \% \mathrm{MFD}$, and R3 $=0 \%$ fish meal $+5 \%$ MFD. The variables measured were feed consumption, average daily gain and feed efficiency. Statistical analysis was done according to the procedure using analysis of variance. Results obtained in the research showed that treatments did not affected significantly feed consumption, average daily gain and feed efficiency of local grower chicken. Therefore, it can be concluded that MFD can be used as the candidate ingredient replacing fish meal in ration of the local grower chicken.

Key words: Manure flour degraded, fish meal, black fly, kampong growing chicken.

\section{PENDAHULUAN}

Ayam buras merupakan ayam lokal di Indonesia yang kehidupannya sudah dikenal oleh masyarakat. Muryanto et al. (1994), penampilan ayam buras sangat 
beragam, begitu pula sifat genetiknya, penyebarannya sangat luas karena populasinya dijumpai di kota maupun di desa. Potensinya patut dikembangkan untuk meningkatkan gizi masyarakat dan menaikan pendapatan keluarga, bilamana dikelola secara intensif atau semi intensif. Pemeliharaan intensif artinya ayam bukan ras tersebut dipelihara menyerupai ayam ras, ayamnya dikurung terus menerus dan diberi ransum secukupnya sesuai dengan kebutuhannya baik dalam jumlah maupun nilai gizi ransum. Sedangkan pemeliharaan semi intensif adalah ayamnya juga dikurung namun diberi umbaran (suatu lokasi yang terbatas yang berhubungan langsung dengan kandangnya), sehingga ayam merasa bebas dan masih dapat mengkonsumsi makanan di umbaran berupa hijauan dan lain-lain (Sakaria dan Wawo, 2004). Permasalahan dalam pengembangan ayam buras di pedesaan antara lain adalah skala usaha kecil (pemilikan induk betina kurang dari 10 ekor), produksi telur rendah, berkisar antara 30-40 butir/tahun, pertumbuhan lambat, mortalitas tinggi akibat penyakit ND, biaya pakan tinggi, dan diusahakan secara perorangan dengan pemeliharaan tradisional (Muryanto et al. 1994a). Peningkatan produksi dan reproduksi ayam buras antara lain dipengaruhi oleh pakan yang diberikan (Muryanto et al. 1994c), terutama kandungan asam lemak esensial yang berhubungan dengan integritas struktur membran mitokondria dalam organ-organ reproduksi dan fosfolipid sebagai prekusor pembentukan kolesterol. Sampai saat ini standar gizi ransum ayam kampung yang dipakai di Indonesia didasarkan rekomendasi Scott et al. (1982) dan NRC (1994). Menurut Scott et al. (1982) kebutuhan energi termetabolis ayam tipe ringan umur 2-8 minggu antara 2600$3100 \mathrm{kkal} / \mathrm{kg}$ dan protein pakan antara $18 \%$ - 21,4\% sedangkan menurut NRC (1994) kebutuhan energi termetabolis dan protein masing - masing $2900 \mathrm{kkal} / \mathrm{kg}$ dan $18 \%$. Standar tersebut sebenarnya adalah untuk ayam ras, sedangkan standar kebutuhan energi dan protein untuk ayam kampung yang dipelihara di daerah tropis belum ada. Oleh sebab itu kebutuhan energi dan protein untuk ayam kampung di Indonesia perlu diteliti. Kandungan protein menentukan harga ransum sehingga bahan ransum alternatif yang murah dengan kandungan protein tinggi terus diupayakan. Tepung ikan merupakan tepung yang diperoleh dari penggilingan ikan dan termasuk bahan essensial yang sangat diperlukan untuk campuran ransum ternak sebagai sumber protein untuk mempercepat pertambahan berat badan ternak. Penggunaan tepung ikan menentukan harga ransum ternak, oleh karena itu tepung ikan dapat diganti dengan bahan makanan lain sebagai sumber protein hewani dengan 
demikian harga ransum dapat ditekan tanpa mengurangi kualitas ransum. Salah satu bahan ransum alternatif yang mudah didapat, murah dan dapat digunakan untuk mengganti tepung ikan adalah tepung manure hasil degradasi larva $H$. illucens $L$. Tepung manure hasil degradasi larva $H$. illucens $L$ berpotensi sebagai sumber protein yang murah dan kontinuitasnya terjamin karena banyak tersedia di alam. Tepung manure hasil degradasi larva $H$. illucens $L$ dapat dijadikan ransum pengganti tepung ikan baik sebagian maupun keseluruhan karena kandungan proteinnya yang tinggi. Larva merupakan salah satu jenis pakan alami yang memiliki protein tinggi. Larva mengandung $41-42 \%$ protein kasar, 31-35\% ekstrak eter, 14-15\% abu, $4.8-5.1 \%$ kalsium, dan 0.60-0.63\% fosfor dalam bentuk kering (Bondari and Sheppard, 1987). Setelah manure hasil degradasi larva lalat hitam menjadi tepung kandungan protein nya mencapai $51,15 \%$ (Manangkot 2014). Berdasarkan pemikiran di atas telah dilakukan penelitian dengan menggunakan ayam buras betina untuk mengetahui pemanfaatan manure hasil degradasi larva lalat hitam (Hermetia illucens $L$ ) sebagai pengganti tepung ikan terhadap penampilan ayam buras betina fase grower.

\section{MATERI DAN METODE PENELITIAN}

Penelitian ini dilaksanakan di Desa Tonsealama Kecamatan Tondano Utara Kabupaten Minahasa yang berlangsung selama 2 bulan 16 hari, dimulai pada 8 Desember 2016 sampai 24 februari 2017. Penelitian ini menggunakan 40 ekor ayam buras betina fase grower umur 16 minggu (4 bulan). Bahan perlakuan menggunakan tepung manure hasil degradasi larva lalat hitam (H. illucens $L)$. Penelitian ini menggunakan 20 unit kandang sistim baterai dengan ukuran $50 \mathrm{~cm}$ x $50 \mathrm{~cm}$ x 75 $\mathrm{cm}$. Setiap unit kandang dilengkapi dengan tempat makan serta minum. Peralatan lain yang digunakan adalah timbangan biasa dan timbangan analitik untuk menimbang ransum, berat badan ayam. Juga dilengkapi dengan alat penerangan listrik. Setiap Perlakuan ditempatkan secara acak. Ransum perlakuan yang diberikan ada 4 macam dengan perbedaan perbedaan tingkat penggunaan tepung manure hasil degradasi larva $H$. illucens $L$ sebagai pengganti tepung ikan sebagai berikut :

$\mathrm{R} 0=0 \%$ tepung $\mathrm{MHD}+15 \%$ tepung ikan; $\mathrm{R} 1=5 \%$ tepung $\mathrm{MHD}+10 \%$ tepung ikan; $\mathrm{R} 2=10 \%$ tepung MHD $+5 \%$ tepung ikan dan R3 $=15 \%$ tepung MHD $+0 \%$ tepung ikan. 
Tabel 1. Komposisi Zat-zat Bahan Makanan Ransum Penelitian

\begin{tabular}{lcccccc}
\hline Bahan Makanan & $\begin{array}{c}\text { Protein } \\
\%\end{array}$ & $\begin{array}{c}\text { SK } \\
\%\end{array}$ & $\begin{array}{c}\text { Lemak } \\
\%\end{array}$ & $\begin{array}{c}\text { Ca } \\
\%\end{array}$ & $\begin{array}{c}\text { P } \\
\%\end{array}$ & $\begin{array}{c}\text { EM } \\
\%\end{array}$ \\
\hline Jagung * & 8,80 & 2,80 & 3,80 & 0,01 & 0,28 & 3350 \\
Dedak halus* & 12,90 & 12,72 & 10,00 & 0,07 & 1,50 & 2100 \\
Bungkil kelapa* & 22,00 & 14,93 & 12,96 & 0,45 & 0,54 & 3327 \\
Tepung ikan* & 50,08 & 0,70 & 6,40 & 6,11 & 2,88 & 2820 \\
Tepung MHD** & 51,15 & 2,06 & 2,75 & 9,84 & 3,2 & 2940 \\
Premix-A & & & & & \\
* Berdasarkan hasil analisis Laboratorium Kimia Balai Penelitian Ternak Ciawi Bogor 1998. \\
** Hasil analisa UPT. Laboratorium Analitik Bukit Jimbaran Udayana \\
Denpasar Bali (Manangkot, 2014)
\end{tabular}

Tabel 2. Bahan makanan yang digunakan dalam penelitian

\begin{tabular}{lllll}
\hline \multirow{3}{*}{ Bahan Makanan } & \multicolumn{5}{c}{ Perlakuan } \\
\cline { 2 - 5 } & $\begin{array}{c}\text { R0 } \\
\%\end{array}$ & $\begin{array}{c}\text { R1 } \\
\%\end{array}$ & $\begin{array}{c}\text { R2 } \\
\%\end{array}$ & $\begin{array}{c}\text { R3 } \\
\%\end{array}$ \\
\hline Jagung Kuning & 60 & 60 & 60 & 60 \\
Dedak Halus & 11,5 & 11,5 & 11,5 & 11,5 \\
Bungkil Kelapa & 12 & 12 & 12 & 12 \\
Tepung Ikan & 15 & 10 & 5 & 0 \\
Tepung MHD & 0 & 5 & 10 & 15 \\
Tepung Tulang & 1 & 1 & 1 & 1 \\
Premix - A & 0,5 & 0,5 & 0,5 & 0,5 \\
\hline & 100 & 100 & 100 & 100 \\
\hline
\end{tabular}

Tabel 3. Komposisi zat-zat makanan

\begin{tabular}{lcccc}
\hline Zat-zat & R0 & R1 & R2 & R3 \\
Makanan & 16,91 & 16,97 & 17,02 & 17,07 \\
\hline Protein & 5,04 & 5,24 & 5,1 & 5,18 \\
Serat Kasar & 5,64 & 5,25 & 5,63 & 5,38 \\
Lemak & 1,00 & 1,18 & 1,37 & 1,56 \\
Kalsium (Ca) & 0,85 & 0,88 & 0,88 & 0,91 \\
Phosphor (P) & 2908,4 & 2914,4 & 2920,4 & 2926,4 \\
M.E Kkal/Kg & & & \\
\hline
\end{tabular}

Percobaan ini dilakukan dengan menggunakan rancangan acak lengkap (RAL) yang terdiri dari 4 perlakuan dan 5 ulangan. Data hasil penelitian ditabulasi, kemudian diuji menurut analisis keragaman untuk melihat pengaruh perlakuan. Data di 
analisis secara statistik menggunakan analisis ragam dengan rancangan acak lengkap (RAL) (Steel and Torrie, 1994).

\section{Variabel yang diukur:}

a. Konsumsi ransum (gram) dihitung berdasarkan jumlah ransum yang diberikan (g/ekor/hari), dikurangi dengan jumlah pakan yang tersisa (g/ekor/hari).

b. Pertambahan berat badan (gram) yaitu diperoleh dari selisih antara berat badan akhir dan berat badan awal penimbangan

c. Efisiensi Penggunaan Makanan dapat diukur berdasarkan perbandingan antara pertambahan berat badan dengan jumlah ransum yang di kosumsi selama periode penelitian.

\section{HASIL DAN PEMBAHASAN}

\section{Pengaruh Penggunaan Tepung Manure Hasil Degradasi Larva Lalat Hitam Terhadap Konsumsi Ransum, Pertambahan Berat Badan, Efisiensi Penggunaan Ransum.}

Hasil pengamatan dan perhitungan rataan konsumsi ransum dari masing masing perlakuan yang diberikan selama percobaan. Rataan konsumsi ransum per ekor per hari untuk masing-masing perlakuan selama percobaan. Dari Rataan dapat dilihat bahwa peningkatan level tepung manure hasil degradasi (MHD) dalam pakan/ransum ayam bukan ras (buras) didapatkan rata-rata konsumsi ransum yang bervariasi dari 91,80692,656 gram per ekor per hari selama dua bulan, sejak ayam berumur 4 bulan sampai dengan umur 6 bulan. Hasil analisis ragam menunjukan bahwa pemberian tepung manure hasil degradasi larva lalat hitam pada ransum ayam buras memberikan pengaruh yang tidak nyata $(\mathrm{P}>0.05)$ terhadap konsumsi ransum. Rataan konsumsi ransum per ekor pada perlakuan berkisar antara 91,81 sampai 92,66 gram/ekor/hari Selama dua bulan sejak ayam umur 16 minggu sampai umur 24 minggu. Rataan tersebut dapat dilihat bahwa konsumsi ransum relatif sama. Kisaran ini masih sesuai dengan standar kebutuhan yang direkomendasikan oleh Selanjutnya Manangkot menyatakan hasil penelitiannya pada ayam buras pedaging umur 2-6 bulan dengan memanfaatkan tepung MHD sampai $15 \%$ menggantikan tepung ikan pada parameter konsumsi ransum berkisar antara 127,095130,230 gram/ekor/hr. Berdasarkan hasil analisis keragaman menunjukkan bahwa perlakuan tidak memperlihatkan adanya perbedaan yang nyata $(\mathrm{P}>0,05)$ terhadap konsumsi ransum, ini berarti bahwa penggantian tepung ikan dengan tepung manure hasil degradasi (MHD) sampai 
Tabel 4. Rataan Konsumsi, Pertambahan Berat Badan, Efisiensi Penggunaan Makanan.

\begin{tabular}{lcccc}
\hline \multirow{2}{*}{ Rataan } & \multicolumn{3}{c}{ Perlakuan } \\
\cline { 2 - 5 } & $\mathrm{R} 0$ & $\mathrm{R} 1$ & $\mathrm{R} 2$ & $\mathrm{R} 3$ \\
\hline Konsumsi & 91,81 & 91,68 & 92,65 & 92,656 \\
PBB & 9,34 & 8,41 & 8,55 & 8,36 \\
Eefisiensi & 0,101 & 0,091 & 0,092 & 0,090 \\
\hline
\end{tabular}

level $15 \%$ dalam ransum ayam buras betina fase grower ini memberikan pengaruh yang sama terhadap konsumsi ransum. Tidak berbedanya konsumsi ransum di sebabkan sebagian besar kandungan zat-zat makanan dalam ransum percobaan adalah relative sama terutama perbandingan energi dan protein. Wahyu (2004) menyatakan bahwa konsumsi ransum dipengaruhi oleh zat-zat makanan yang terkandung dalam ransum dan harus disesuaikan dengan umur dan kebutuhan ternak sebab pakan memiliki peranan penting untuk menjamin kelangsungan hidup ternak dan produksinya. Selanjutnya menurut Manangkot (2014), pada larva terdapat beberapa enzim yaitu protese, amilase, lipase yang bermanfaat dan berperan pada larva H.illucens L, untuk merombak manure ayam sehingga terjadi degradasi. Konsumsi ransum diperoleh dari selisih antara jumlah ransum yang di berikan dengan sisa ransum setiap hari selama penelitian (Anggorodi, 1985).

Pada Tabel 4, dapat dilihat bahwa peningkatan level tepung manure hasil degradasi (MHD) dalam ransum ayam buras betina diperoleh rata-rata pertambahan berat badan bervariasi antara 8,36 - 9,34 (41,83 - 46,72) gram per ekor per hari dengan berat akhir 1,6 - 1,8 kg pada umur 6 bulan. Scott et al. (1982), ayam broiler adalah 45,7 - 50 gram per ekor per hari (2-2,2 kg). Hasil penelitian Manangkot (2014) menyatakan bahwa level tepung manure hasil degradasi (MHD) dalam ransum ayam buras pedaging diperoleh rata-rata pertambahan berat badan bervariasi antara 45,854 - 49,582 gram per ekor per hari (2-2,2 kg/ekor). Hasil analisis keragaman menunjukkan bahwa perlakuan yang diberikan tidak memperlihatkan adanya perbedaan yang nyata $(\mathrm{P}>0,05)$ terhadap pertambahan berat badan, ini berarti bahwa penggantian tepung ikan dengan tepung MHD sampai level 15\% dalam ransum ayam buras pedaging memberikan pengaruh yang sama terhadap pertambhan berat badan. Pertambahan berat badan yang tidak berbeda ini asumsinya disebabkan karena konsumsi ransum yang tidak berbeda seperti halnya yang dikatakan Anggorodi (1985) bahwa antara konsumsi ransum dengan pertambahan berat badan mempunyai hubungan yang sangat erat. Pertambahan berat badan diperoleh dari 
selisih antara berat badan akhir dan berat badan awal selama penelitian. Hasil pengamatan dan perhitungan terhadap rataan efisiensi penggunaan ransum per ekor per hari dari masing-masing perlakuan selama percobaan.

Pada Tabel 4, Rataan penelitian menunjukkan angka efisiensi penggunaan makanan yang bervariasi antara 0,09030,1017. Sebagaimana yang dinyatakan oleh Anggorodi (1985) bahwa efisiensi penggunaan makanan dipengaruhi oleh penggunaan zat-zat makanan setelah mengalami proses pencernaan oleh ternak. Hasil penelitian oleh Manangkot (2014), bahwa efisiensi penggunaan makanan pada ayam buras pedaging bervariasi antara 0,3608-0,3805. Efisiensi penggunaan ransum dapat diukur berdasarkan perbandingan antara pertambahan berat badan dengan jumlah ransum yang dikonsumsi selama waktu tertentu (Rasyaf, 2002). Hasil analisis ragam menunjukan bahwa pemberian tepung manure hasil degradasi (MHD) larva lalat hitam pada ayam buras betina fase grower tidak memberikan pengaruh yang nyata $(\mathrm{P}>0,05)$ terhadap efisiensi penggunaan ransum. Wahyu (2004) mengemukakan bahwa secara umum efisiensi penggunaan makanan dipengaruhi oleh jumlah konsumsi. Efisiensi penggunaan makanan yang sama disebabkan karena konsumsi ransum dan pertambahan berat badan sama, dapat dilihat pada R3 yang menunjukkan angka yang sama rendah diasumsikan bahwa transformasi setiap ransum perlakuan menjadi produk daging adalah sama atau proses transformasi zat-zat makanan untuk disintesa menjadi organ atau jaringan tubuh adalah sama. Sebagaimana yang dinyatakan oleh Anggorodi (1985) bahwa efisiensi penggunaan makanan dipengaruhi oleh penggunaan zat-zat makanan setelah mengalami proses pencernaan oleh ternak. Efisiensi penggunaan ransum diperoleh berdasarkan perbandingan antara rata-rata pertambahan berat dengan rata-rata konsumsi pakan/ransum selama penelitian (Tilman, 1991). Mengacu pada hasil penelitian secara keseluruhan bahwa penggantian tepung manure hasil degradasi (MHD) dengan tepung ikan, semakin rendah angka efisiensi penggunaan ransum ternak ayam buras betina fase grower, khususnya pada perlakuan R3 atau level penggantian $100 \%$. Ini disebabkan oleh angka konsumsi dan pertambahan berat badan, keduanya menunjukkan pola penurunan yang sama, sehingga angka efisiensi penggunaan ransum ikut menurun.

\section{KESIMPULAN}

Hasil penelitian menunjukan bahwa pemanfaatan tepung manure hasil degradasi larva lalat hitam (Hermetia illucens $L$ ) 
MHD dengan umur manure 14 hari dan umur larva 8 hari untuk konsumsi ransum, pertambahan berat badan dan efisiensi penggunaan ransum dapat dimanfaatkan sampai level $15 \%$ dalam ransum ayam buras betina fase grower.

\section{DAFTAR PUSTAKA}

Anggorodi, 1985. Kemampuan Mutahir Dalam Ilmu Makanan Ternak Unggas. Universitas Indonesia Press. Jakarta.

Bondari K. and Sheppard D. C. 1987. Soldier fly, Hermetia illuscens $L$., larvae as feed for channel catfish, Ictalurus punctatus (Rafinesque), and blue tilapia, Oreochromis aureus (Steindachner). Aquaculture and Fisheries Management 18: 209220.

Manangkot, H.J. 2014, Black soldier fly larvae manure degradation as fish meal replacer in native chicken ration. Seria Zootehnie 62:139-142.

Muryanto, Subiharta, dan D.M. Juwowo 1994a. study manajemen produksi telur tetas pada pemeliharaan ayam buras di pedesaan. Jurnal Ilmiah Penelitian Ternak Klepu 1(2): 98114.

Muryanto, Subiharta, dan D.M. Juwowo, dan W. Dirdjopranoto. 1994b. Optimalisasi produksi telur ayam buras melalui perbaikan pakan dan tata laksana pemeliharaan. Jurnal Ilmiah Penelitian Ternak Klepu 1(2): 9-14.

Sakaria, S. dan B. Wawo. 2004. Penyusunan Ransum Ayam Buras Secara Sederhana. Hasil Penelitian. tidak dipublikasikan. Fakultas Peternakan Universitas Hasanudin.

Scott, M.L.S.J and Mullenhoff. 1982. The calcium requirements of laying hens and effect of clodietary oyster shell upon egg shell quality. Poultry Sci. 50:1055-1063.

Steel, R.G.D dan J.H Torrie. 1991. Prinsip dan Prosedur Statistika. Diterjemahkan oleh Bambang sumantri. Edisi ke-2. PT. Gramedia Pustaka Utama. Jakarta.

Wahyu, J. 2004. Ilmu Nutrisi Unggas. Gadjah Mada. University Prees. Jogjakarta. 